SCIENTIFIC NOTE

\title{
Effect of drying methods on the chemical composition, colour, functional and pasting properties of plantain (Musa parasidiaca) flour
}

\author{
Gbemisola Jamiu Fadimu $^{1 *}$, Lateef Oladimeji Sanni ${ }^{1}$, AbdulRasaq Adebowale ${ }^{1}$, Sarafadeen Kareem ${ }^{2}$, Olajide \\ Paul Sobukola $^{1}$, Olatundun Kajihausa ${ }^{1}$, Abdulsam-Saghir ${ }^{3}$, Bernard Siwoku ${ }^{4}$, Aminat Akinsanya ${ }^{4}$, Monilola \\ Kudirat Adenekan ${ }^{5}$
}
1 Department of Food Science and Technology, Federal University of Agriculture, Abeokuta, Nigeria.
2 Department of Microbiology, Federal University of Agriculture, Abeokuta, Nigeria
3 Department of Agricultural Extension and Rural Development, Federal University of Agriculture, Abeokuta, Nigeria
${ }^{4}$ CAVA II (Nigeria), Department of Food Science and Technology, Federal University of Agriculture, Abeokuta, Nigeria
${ }_{5}$ Department of Food Technology, Moshood Abiola Polytechnic, Ojere, Abeokuta, Nigeria

* Corresponding author: fadimugbemisola@gmail.com

\begin{abstract}
The demand for plantain flour has increased in recent years due to its health benefits and industrial applications and information on the effect of drying methods on the physicochemical and functional characteristics of plantain flour in literature is limited. This present study was conducted to determine the effect of drying methods on the chemical, colour, functional and pasting properties of plantain flour were investigated. The results revealed that drying methods significantly $(p<0.05)$ affected all the parameters studied. The moisture content of the flours ranged between $8.18-11.50 \%$, fibre $2.56-3.21 \%$, ash $3.00-3.30 \%$ and carbohydrate $76.18-80.49 \%$. The L $L^{*}$ of the samples ranged between 95.90 - 96.98, while the peak viscosity ranged between $432.04-461.37$ RVU, final viscosity $320.40-484.58$ RVU and pasting temperature 81.25 $-83.20^{\circ} \mathrm{C}$ across the drying methods used. Bulk density values varied between $0.68-0.70 \mathrm{~g} / \mathrm{ml}$, WAC between $115.5-149.8 \%$, OAC between $110.55-115.55 \%$ and swelling power 31.85 - 3.54\%. Determination of suitable drying method is necessary for production of good quality plantain flour and the result suggest that any drying method could be used to produce good quality plantain flour.

Keywords: Proximate, colour, pasting, functional properties, plantain flour, pretreatment
\end{abstract}

\section{Introduction}

Plantains (Musa parasidiaca) is one of the important staple food crops consumed in the tropics behind rice, wheat and maize and are obtainable in about 120-130 tropical countries in the world (Kawongolo, 2013). It is an essential food crop in sub-Sahara Africa that serves as source of nutrient and household income for many people around the world (Kawongolo, 2013). The aggregated world production is put at over 76 million metric tons (Olumba, 2014), out of which over 12 million metric tons are harvested yearly in Africa (Fakayode et al., 2011). Sizeable tons of plantains are harvested in Nigeria annually and Nigeria is the biggest producer of plantains in West Africa with an estimated production of about 2.7 million metric tons, majority of which are produced and harvested from the southern part of the country (FAO, 2009). In spite of large tons of plantains harvested yearly in Nigeria, Olorunda and Adelusola (1997) reported that over $50 \%$ of plantains harvested are lost due to unavailability of appropriate storage facilities to prevent postharvest losses. These large productions and post-harvest losses necessitate the need to develop new and suitable technologies for processing and preservation of plantain flour for time to come. Usually harvested at matured but unripe stage, plantains undergo rapid respiration after harvest, making it a shortlived agricultural product that requires urgent attention immediately after harvest. Plantain may therefore be processed into flour when it is matured but not ripe. Traditionally, sun drying is the common method used in processing plantains into flour. However, there are some problems associated with sun drying such as slowness of the process, uncertainty of the weather and uneven drying (Arinola et al., 2016). Falade (2009) reported that drying is one of the best methods in terms of cost efficiency to preserve plantain flour in other to have plantain product with considerable shelf stability. Drying serves as a suitable and cheap means for removing water from plantain which adds value to plantain and this result in production of convenience product having suitable shelf life (Demirel and Turhan, 2003).

Drying is one of the best techniques used in the processing of agricultural produce and many researches have been done on the drying of different agricultural produce. It is basically done to reduce moisture below levels required for microbial and enzymatic reactions (Doymaz, 2007). According to Arinola et al., (2016), different drying methods can be used for drying plantain fruits. Microwave oven and freeze-drying have been previously used to dry plantain flour (Emperatriz 
et al., 2008). The effects of freeze-drying, drum drying and microwave oven drying on quality attributes of plantain flour have been reported. The need for a hygienic, effective drying method is apparent. The end use of plantain flour in food depends on the attractiveness of its colour. Enzymatic browning reaction is one of the problems encountered during plantain processing and this reaction often affects the colour of the flour produced from plantain. The browning reactions usually occur during processing as a result of the activity of polyphenol oxidase which is also known as tyrosinase (Carbonaro \& Mattera, 2002). It is therefore essential to pretreat plantain slices during processing to arrest the browning, which if not arrested may affect the colour of the final product. Information on the effects of drying methods on the proximate composition, functional, colour and pasting properties of plantain flours is scarce in literature. Therefore, to intensify the use of plantain flour in food products, it is necessary to establish the best drying method to produce plantain flour of good quality. The objectives of the study were to determine the effect of drying methods on the proximate composition, functional, colour and pasting properties of plantain flours.

\section{Materials and Methods}

\section{Materials}

The matured unripe plantain fruits for this study were purchased from the Teaching and Research Farm of Federal University of Agriculture, Abeokuta, Nigeria. Plantain of the same variety and maturity level were carefully selected, while the stage of ripeness was determined using colour chat. The potassium metabisulphite used was purchased from Sigma chemicals, (St. Louis, MO, U.S.A).

\section{Preparation of plantain flour}

The selected plantains fruits were processed in the laboratory of Department of Food Science and Technology, Federal University of Agriculture, Abeokuta, Nigeria. The plantain fruits were washed, hand-peeled and sliced using plantain slicer in other to obtain slices of the same thickness. The slices were blanched in hot water at $50{ }^{\circ} \mathrm{C}$ for 7 mins and sulphited using $1 \%$ potassium metabisulphite concentration. The pretreated samples were then dried using cabinet, solar, sun and oven drying methods. They were then milled and stored in ziplock bags for further analysis (Zakpaa et al., 2010). The plantain flours were coded as follows: $\mathrm{CAPF}=$ Cabinet dried plantain flour, SOPF $=$ Solar dried plantain flour, SUPF $=$ Sun dried plantain flour and OVPF $=$ Oven dried plantain flour.

Cabinet drying: The samples were dried using cabinet dryer (LEEC Limited, Serial No 3114, Nottingham UK) at 60 ${ }^{\circ} \mathrm{C}$ for $24 \mathrm{~h}$

Oven drying: The plantain slices were dried using Gallenkamp oven (Model OV-160) at $60{ }^{\circ} \mathrm{C}$ for $24 \mathrm{~h}$

Solar drying: Direct natural convection solar dryer designed and constructed by Department of Food Science and Technology, Federal University of Agriculture, Abeokuta, Nigeria was used for this study. It is constructed with bricks on the sides and a transparent glass covering the top inclined at an angle of $10^{\circ}$ to face the equator. The interior of the solar house is painted black to improve absorption of heat. The drying was done in the solar house at $50^{\circ} \mathrm{C}$ for $48 \mathrm{~h}$. The experiment was conducted in summer when daytime sunlight was maximum (between 8 am and 5pm) and during night hours, the drying temperature was maintained by heating the inner chamber of the solar house overnight and the temperature was constantly monitored using probe thermometer.

Sun drying: The samples was kept in the sun between 8:30 am to 5:00 pm daily and was dried to constant weight for three days.

Analyses of the functional properties and proximate composition of the samples

The samples were evaluated for functional properties and proximate composition. The bulk density of the plantain flour were determined using the method described by Mpotokwane et al. (2008), water and oil absorption capacity as described by Sathe and Salunkhe (1981), least gelation capacity as described by Oluwalana et al. (2011), swelling power as described by (Leach et al., 1957), dispersibility and wettability as described by Kulkarni and Ingle (1991). The proximate composition of the plantain flours were determined using standard AOAC 2003 methods.

\section{Analysis of colour properties of the samples}

Chroma meter (CR-410, Konica Minolta Sensing Inc., Osaka, Japan) was used to determine the colour parameters $\left(\mathrm{L}^{*}, \mathrm{a}^{*}, \mathrm{~b}^{*}\right)$ of the plantain flour samples. The colorimeter was standardized and the samples were placed in the sample holder. The colour measurement was done in triplicates.

\section{Analysis of pasting properties of the samples}

Rapid Visco Analyser (RVA Techmaster) was used to determine the pasting properties of the plantain flour using the General RVA Pasting Method (Newport Scientific Pty Limited, Warriewood, Australia). $3 \mathrm{~g}$ of the plantain flour sample was mixed with $25 \mathrm{ml}$ of distilled water inside the RVA test canister and this was lowered into the RVA system. The slurry was heated from 50 to $95^{\circ} \mathrm{C}$ and cooled back to $50^{\circ} \mathrm{C}$ within $12 \mathrm{~min}$, rotating the can at a speed of $160 \mathrm{rpm}$ with continuous stirring of the content with a plastic paddle. The parameters measured were peak viscosity, trough, breakdown viscosity, setback viscosity, final viscosity, pasting temperature and time (Newport Scientific, 1998).

\section{Statistical analysis}

All analysis were conducted in triplicate. The results were expressed as the mean \pm standard deviation. Statistical analysis was carried out using one-way analysis of variance (ANOVA) with IBM SPSS 21.0 version (Michigan State University, East Lansing, MI). Duncan's multiple range test was used for mean separation

\section{Results and discussion}

\section{Effect of Drying Methods on the Functional Properties of the Plantain Flours}

Effects of drying methods on the functional properties of plantain flours are shown on Table 1 . The results revealed that bulk density and water absorption capacity (WAC) of the plantain flours were significantly $(\mathrm{p}<0.05)$ affected by drying met- 
hods. The bulk density of the samples varied from $0.68-0.70$ $\mathrm{g} / \mathrm{ml}$. Bulk densities of cabinet dried plantain flour (CAPF) and oven dried plantain flour (OVPF) were not different $(0.70 \mathrm{~g} /$ $\mathrm{ml}$ ), while sun dried plantain flour (SUPF) had the lowest. This implies that the particle size of CAPF and OVPF were higher compare to that of solar dried plantain flour (SOPF) and sun dried plantain flour (SUPF). Bulk density has effect on the packaging and transportation of food materials and higher bulk products present better packaging properties than those with low bulk density (Fagbemi, 1999). Bulk density of starchy products are often affected by gelatinization during processing, and the granular structure of starch is completely loss (Tho- mas and Atwell, 1999). The result obtained for bulk density in this present study is higher than the values $(0.55-0.60 \mathrm{~g} /$ $\mathrm{ml}$ ) reported for plantain flour by Falade (2010) and lower than values reported by Arinola et al. (2016) for plantain flour. The relative difference in the bulk density could be attributed to the difference in variety of the plantain used as well as the particle size of the flour.

Drying methods significantly $(\mathrm{p}<0.05)$ affected the water absorption capacity (WAC) of the plantain flours and the values obtained ranged between 115.5 to $149.8 \%$. Water absorption

Table 1: Effects of drying methods on the functional properties of plantain flour

\begin{tabular}{|l|c|c|c|c|}
\hline Parameters & CAPF & SOPF & SUPF & OVPF \\
\hline Bulk density $(\mathrm{g} / \mathrm{ml})$ & $0.70 \pm 0.00^{\mathrm{a}}$ & $0.69 \pm 0.01^{\mathrm{ab}}$ & $0.68 \pm 0.00^{\mathrm{b}}$ & $0.70 \pm 0.00^{\mathrm{a}}$ \\
\hline WAC (\%) & $148.5 \pm 1.41^{\mathrm{a}}$ & $121.5 \pm 0.00^{\mathrm{b}}$ & $115.5 \pm 0.70^{\mathrm{c}}$ & $149.8 \pm 0.84^{\mathrm{a}}$ \\
\hline OAC (\%) & $114.85 \pm 3.32^{\mathrm{a}}$ & $110.55 \pm 7.14^{\mathrm{a}}$ & $112.05 \pm 3.74^{\mathrm{a}}$ & $115.55 \pm 4.59^{\mathrm{a}}$ \\
\hline Dispersibility (\%) & $70.0 \pm 1.41^{\mathrm{b}}$ & $73.0 \pm 0.70^{\mathrm{b}}$ & $77.5 \pm 2.12^{\mathrm{a}}$ & $80.5 \pm 0.70^{\mathrm{a}}$ \\
\hline Wettability (\%) & $128.0 \pm 1.41^{\mathrm{b}}$ & $125.5 \pm 0.70^{\mathrm{b}}$ & $134.0 \pm 0.00^{\mathrm{a}}$ & $135.0 \pm 1.41^{\mathrm{a}}$ \\
\hline LGC (\%) & $8 \pm 0.00^{\mathrm{a}}$ & $6 \pm 0.00^{\mathrm{a}}$ & $6 \pm 0.00^{\mathrm{a}}$ & $6 \pm 0.00^{\mathrm{a}}$ \\
\hline Swelling Power (\%) & $39.54 \pm 1.10^{\mathrm{a}}$ & $31.85 \pm 1.74^{\mathrm{c}}$ & $35.47 \pm 0.14^{\mathrm{b}}$ & $32.48 \pm 1.08^{\mathrm{c}}$ \\
\hline
\end{tabular}

* Mean values with the same superscript within the same row are not significantly $(p<0.05)$ different

** CAPF - Cabinet dried plantain flour, SOPF - Solar dried plantain flour, SUPF - Sun-dried plantain flour, OVPF - Oven dried plantain flour, WAC - Water absorption capacity, OAC - Oil absorption capacity, LGC - Least gelation concentration

capacity is the ability of flour to absorb water and swell for improved consistency during food preparation. According to Osundahunsi et al. (2003), higher water absorption capacity could improve yield and consistency and also give body to food. In addition to starchy component of flour, fibre, protein and fat also contribute to water absorption capacity. OVPF and CAPF had significantly $(\mathrm{p}<0.05)$ higher water absorption capacity than the SOPF and SUPF. The values reported in this work were higher than those reported by Oluwalana and Oluwamukomi (2011). Regardless of the drying method used, the water absorption capacity of the plantain flour samples was generally high. This is an indication that the plantain flour could be useful in baked and other products that require hydration to improve handling characteristics.

Oil absorption capacity (OAC) is an important quality parameter of flour since oil acts as flavor retainer and increases the mouth feel of food (Aremu et al, 2009). The OAC of the plantain flour ranged between 110.55 to $115.55 \%$ and were not significantly $(\mathrm{p}>0.05)$ different. Also, the reconstitution properties (wettability and dispersibility) of the plantain flour were significantly $(\mathrm{p}<0.05)$ affected by drying methods. SUPF and SOPF showed significantly higher dispersibilitiy and wettability than CAPF and OVPF. This implies that SUPF and SOPF would reconstitute faster than CAPF and OVPF in water. In addition, swelling power values of CAPF was significantly $(p<0.05)$ higher than SUPF, SOPF and OVPF while SOPF and OVPF were not significantly different. Swelling power show the degree of exposure of the internal structure of starch granules to action of water, that is, a measure of hydration capa- city (Arinola et al. 2016). The results of swelling power in this present study indicate that the different drying methods caused slight aggregation of starch granules to different degrees and subsequently affect the level of its exposure to water and its swelling power. The LGC of all the plantain flour samples were not significantly ( $>0.05)$ affected by drying methods.

Effect of Drying Methods on the Proximate Properties of the Plantain Flours

Table 2 shows the proximate composition of the plantain flour. As observed on the table, drying methods significantly affected the proximate composition of the plantain flours. The moisture content of the samples ranged from 8.18 to $11.50 \%$ with OVPF showing lowest moisture content while SUPF had the highest. The lower moisture content of the OVPF could be due to effect of heat on the samples during drying. Generally, the moisture content of all the plantain flours obtained in this work were lower than the permissible level for moisture content of food flour according to FAO (2004) which makes the flour safe. The carbohydrate content of the plantain flour ranged between 76.18 to $80.49 \%$ while it was lowest in SUPF (76.18\%), highest value was reported for OVPF. Protein and crude fat were also highest in SUPF $(3.62 \%$ and $2.56 \%$ respectively). However, protein was lowest in OVPF $(2.89 \%)$ and crude fat was also lowest in OVPF. The crude fibre content of OVPF was significantly higher than the fibre content of CAPF, SOPF and SUPF, which were not significantly $(p<0.05)$ different. The ash content of the plantain flours ranged from 3.00 to $3.30 \%$ with OVPF showing lowest value, while SOPF had the highest ash content. 
Table 2: Effects of drying methods on the proximate composition of plantain flour

\begin{tabular}{|l|c|c|c|c|}
\hline Parameters & CAPF & SOPF & SUPF & OVPF \\
\hline Carbohydrate (\%) & $79.73 \pm 0.89^{\mathrm{b}}$ & $78.10 \pm 1.38^{\mathrm{c}}$ & $76.18 \pm 1.09^{\mathrm{d}}$ & $80.49 \pm 2.46^{\mathrm{a}}$ \\
\hline Protein (\%) & $3.21 \pm 0.45^{\mathrm{b}}$ & $3.53 \pm 0.39^{\mathrm{a}}$ & $3.62 \pm 0.83^{\mathrm{a}}$ & $2.89 \pm 0.68^{\mathrm{c}}$ \\
\hline Crude fat (\%) & $2.35 \pm 0.43^{\mathrm{b}}$ & $2.42 \pm 0.01^{\mathrm{ab}}$ & $2.56 \pm 0.09^{\mathrm{a}}$ & $2.15 \pm 0.28^{\mathrm{c}}$ \\
\hline Crude fibre (\%) & $2.64 \pm 0.24^{\mathrm{b}}$ & $2.56 \pm 0.68^{\mathrm{b}}$ & $2.63 \pm 0.72^{\mathrm{b}}$ & $3.21 \pm 0.03^{\mathrm{a}}$ \\
\hline Ash (\%) & $3.20 \pm 0.43^{\mathrm{ab}}$ & $3.30 \pm 0.12^{\mathrm{a}}$ & $3.05 \pm 0.63^{\mathrm{bc}}$ & $3.00 \pm 0.08^{\mathrm{c}}$ \\
\hline Moisture content (\%) & $8.91 \pm 0.98^{\mathrm{c}}$ & $10.18 \pm 1.03^{\mathrm{b}}$ & $11.50 \pm 0.84^{\mathrm{a}}$ & $8.18 \pm 0.76^{\mathrm{d}}$ \\
\hline
\end{tabular}

* Mean values with the same superscript within the same row are not significantly $(p<0.05)$ different

** $\boldsymbol{C A P F}$ - Cabinet dried plantain flour, SOPF - Solar dried plantain flour, SUPF - Sun-dried plantain flour, OVPF - Oven dried plantain flour

Effect of Drying Methods on the Pasting Properties of the Plantain Flours

Table 3 shows the pasting properties of the plantain flours. The pasting properties of flours are used in assessing the suitability of its application as functional ingredient in food and other industrial products (Oluwalana, et al., 2011). The results obtained in this study revealed that drying methods significantly $(p<0.05)$ affected the pasting properties of the plantain flours. The peak viscosity values obtained ranged between 432.04-461.37 RVU and is lower in oven dried plantain flour, but the peak viscosity of cabinet, solar and sun dried plantain flours were not significantly $(\mathrm{p}<0.05)$ different. Peak viscosity is often related with the final product quality, as it indicate the viscous load likely to be encountered during mixing (MaziyaDixon et al., 2004).

Trough viscosity values ranged between $248.92-321.33$ RVU, while the minimum value was reported in sun dried flour, the highest value was reported in oven dried plantain flour. According to Zaidhul et al., (2006), trough viscosity provides information about the breakdown or stability of starch gel during cooking and the lower the value the more stable the starch gel. This indicates that the starch gel of sun dried plantain flour will be more stable than flours dried using other drying methods. The breakdown viscosities recorded in this research work was lower in OVPF and higher in CAPF.

The final viscosity which indicates the ability of starchy foods to form viscous paste after cooking and cooling is an important quality parameter used in predicting and defining the final textural quality of starchy foods (Arinola et al. 2016) In this present work, there was significant $(p<0.05)$ difference in the final viscosity with OVPF having the highest value of 484.58 RVU and plantain flour dried with sun drying method having the lowest value 320.40 RVU.

Setback viscosity which represent the viscosity of starch after $50^{\circ} \mathrm{C}$ is lowest in CAPF, while highest value was reported in OVPF. High setback values have been reported to affect dough digestibility (Shittu et al., 2001), while lower value is beneficial as is indicate lower tendency for retrogradation (Sandhu et al., 2007).

Pasting temperature which measures the minimum temperature needed to cook a given food sample (Sandhu et al., 2005 ) ranged between 81.25 to $83.20^{\circ} \mathrm{C}$. No significant difference was observed in the values. The peak time which measures the cooking time (Adebowale et al., 2005) of starch was higher in oven dried plantain flour. However, the pasting time of other drying methods used were not significantly different.

Table 3: Effect of drying methods on the pasting properties of dried unripe plantain flour

\begin{tabular}{|l|c|c|c|c|}
\hline Parameters & CAPF & SOPF & SUPF & OVPF \\
\hline Peak viscosity (RVU) & $461.37 \pm 0.88^{\mathrm{a}}$ & $451.04 \pm 1.59^{\mathrm{a}}$ & $454.08 \pm 1.12^{\mathrm{a}}$ & $432.04 \pm 9.60^{\mathrm{b}}$ \\
\hline Trough (RVU) & $251.08 \pm 7.19^{\mathrm{bc}}$ & $261.50 \pm 1.65^{\mathrm{b}}$ & $248.92 \pm 1.32^{\mathrm{c}}$ & $321.33 \pm 0.35^{\mathrm{a}}$ \\
\hline Breakdown (RVU) & $210.29 \pm 8.07^{\mathrm{a}}$ & $189.54 \pm 0.05^{\mathrm{b}}$ & $203.46 \pm 2.80^{\mathrm{ab}}$ & $110.71 \pm 9.24^{\mathrm{c}}$ \\
\hline Final viscosity (RVU) & $327.37 \pm 5.59^{\mathrm{c}}$ & $352.08 \pm 0.23^{\mathrm{b}}$ & $320.40 \pm 8.18^{\mathrm{c}}$ & $484.58 \pm 4.94^{\mathrm{a}}$ \\
\hline Setback (RVU) & $76.29 \pm 1.59^{\mathrm{b}}$ & $90.58 \pm 1.88^{\mathrm{b}}$ & $85.54 \pm 9.13^{\mathrm{b}}$ & $163.25 \pm 5.30^{\mathrm{a}}$ \\
\hline Peak time (minutes) & $4.60 \pm 0.09^{\mathrm{b}}$ & $4.60 \pm 0.00^{\mathrm{b}}$ & $4.56 \pm 0.04^{\mathrm{b}}$ & $4.93 \pm 0.09^{\mathrm{a}}$ \\
\hline Pasting temperature $\left({ }^{\circ} \mathrm{C}\right)$ & $81.55 \pm 1.13^{\mathrm{a}}$ & $81.25 \pm 0.49^{\mathrm{a}}$ & $81.50 \pm 0.00^{\mathrm{a}}$ & $83.20 \pm 1.20^{\mathrm{a}}$ \\
\hline
\end{tabular}

*Mean values with the same superscript within the same row are not significantly $(p<0.05)$ different

**CAPF - Cabinet dried plantain flour, SOPF - Solar dried plantain flour, SUPF - Sun-dried plantain flour, OVPF - Oven dried plantain flour, RVU - Rapid Viscous Unit 
Table 4: Effect of drying methods on the colour properties of dried unripe plantain flour

\begin{tabular}{|l|c|c|c|c|c|}
\hline Parameters & FP & CAPF & SOPF & SUPF & OVPF \\
\hline $\mathrm{L}^{*}$ & $98.59 \pm 0.03^{\mathrm{a}}$ & $96.50 \pm 0.23^{\mathrm{c}}$ & $95.90 \pm 0.03^{\mathrm{d}}$ & $96.98 \pm 0.07^{\mathrm{b}}$ & $96.88 \pm 0.14^{\mathrm{bc}}$ \\
\hline $\mathrm{a}^{*}$ & $0.59 \pm 0.00^{\mathrm{a}}$ & $0.36 \pm 0.01^{\mathrm{b}}$ & $0.56 \pm 0.00^{\mathrm{a}}$ & $0.18 \pm 0.04^{\mathrm{c}}$ & $1.02 \pm 0.02^{\mathrm{d}}$ \\
\hline $\mathrm{b}^{*}$ & $12.49 \pm 0.05^{\mathrm{e}}$ & $25.40 \pm 0.03^{\mathrm{d}}$ & $27.39 \pm 0.00^{\mathrm{a}}$ & $25.60 \pm 0.04^{\mathrm{c}}$ & $27.13 \pm 0.09^{\mathrm{b}}$ \\
\hline
\end{tabular}

\begin{abstract}
*Mean values with the same superscript within the same row are not significantly $(p<0.05)$ different
**CAPF - Cabinet dried plantain flour, SOPF - Solar dried plantain flour, SUPF - Sun-dried plantain flour, OVPF - Oven dried plantain flour, FP - Fresh pulp
\end{abstract}

\section{Effect of Drying Methods on the Colour Parameters of the Plantain Flours}

The colour parameters CIE (L, a, b) of the plantain flour samples as affected by drying methods are presented in Table 4 . The table revealed that drying methods significantly $(p<0.05)$ affected the colour parameters of the plantain flours. As presented in Table 4, the colour of the fresh plantain pulp was significantly $(p<0.05)$ different from that of the dried plantain flours. Generally, all the plantain flour samples showed higher CIE L* $\left(95.90\right.$ - 96.98), lower $a^{*}(0.18-1.02)$ and lower $b^{*}(25.40-27.39)$. In addition, the fresh plantain pulp had the highest L value followed by sun dried plantain flour, while solar dried flour had the lowest. However, the L values reported for all the samples are very close and the difference in the Lightness $\left(\mathrm{L}^{*}\right)$ could be attributed to the effect of enzymatic browning which occurred under the conditions prevailing during the drying process, which would favour colour change.

\section{Conclusions}

Drying is one of the oldest methods used to preserve perishable agricultural produce in order to ensure their availability all year round. Drying methods affected the moisture content, colour, functional and pasting properties of dried unripe plantain flour. Oven dried plantain flour had highest water absorption capacity, dispersibility and lowest moisture content, while highest Lightness $\left(\mathrm{L}^{*}\right)$ was reported for Sun dried plantain flour. Oven dried plantain flour had the highest trough, final and setback viscosities and lowest breakdown viscosity Generally, the results obtained from the study revealed that the four drying methods were all good as they all yielded plantain flours of good quality in terms of the parameters studied. However, to obtain plantain flour of high water absorption capacity, dispersibility, oil absorption capacity, wettability, high viscosity and lower tendency for retrogradation and lower moisture content, oven-drying method would likely be recommended.

\section{Acknowledgement}

This research work was financed by World Bank under the Upscaling the Nigerian Flash Drying Experience for Sustainable Regional Trade and Income Generation in West Africa (UDESWA) project.

\section{References}

Adebowale, A. A., Sanni, L. O., Awonorin, S. O. (2005) Effect of Texture Modifiers on the Physicochemical and Sensory Properties of Dried Fufu. Food Science and Technology Institute, 11(5) 373-382.

Adeniji, T. A., Hart, A. D., Tenkouano, A., Barimala, I. S., Sanni, L. O. (2010) Comparative Study of Pasting Properties of Improved Plantain, Banana and Cassava Varieties with Emphasis on Industrial Application. African Journal of Food Agriculture Nutrition and Development, 10(5) 2601- 2614.

Adeniji, T. A., Sanni, L. O., Hart, A. D. (2006) Determination of Micronutrients and Colour Variability Among New Plantain and Banana Hybrids Flours. World Journal of Chemistry, 1 (1) 23-27.

Akpapunan, M.A., Markakis, P. (1981) Physicochemical and nutritional aspects of cowpea flour. Journal of Food Science, 46 972-973.

AOAC (2000) Official Methods of Analysis. Association of Official Analytical Chemists. 17th edition, Washington DC.

AOAC (2003) Official Methods of Analysis. Association of Official Analytical Chemists. 17th edition, Washington DC.

Aremu, M. O., Basu, S. K., Gyar, S. D., Goyal, A., Bhowmik, P., Datta Banik, S. (2009) Proximate Composition and Functional Properties of Mushroom Flours from Ganoderma spp., Omphalotus olearius (DC.) Sing. and Hebeloma mesophaeum (Pers.) Quél. Used in Nasarawa State, Nigeria. Malaysian Journal of Nutrition, 15(2) 233 - 241.

Arinola, S. O., Ogunbusola, E. M., Adebayo, S. F. (2016) Effect of Drying Methods on the Chemical, Pasting and Functional Properties of Unripe Plantain (Musa paradisiaca) Flour. British Journal of Applied Science and Technology, 14(3) 1-7.

Baiyeri K. P, Ortiz, I. (2000) Agronomic Evaluation of Plantain and Other Triploid Musa. In K. Craenen, R. Ortiz, E.B. Karamura, and D.R. Vuylsteke (eds.). Proceeding of First International Conference of Banana and Plantain in Africa, Kampala, Uganda, 12-18 October, 1996. International Society for Horticulture, 540, 125-135.

Baiyeri, K. P., Aba, S. C., Otitoju, G. T., Mbah, O. B. (2011) The Effects of Ripening and Cooking Method on Mineral and Proximate Composition of Plantain (Musa sp AAB cv "Agbagba" Fruit Pulp. Africa Journal of Biotechnology, 10(36) $6979-6984$.

Bowrey, R.G., Buckle, K.A., Hamey, I., Pavenayotin, P. (1980) Use of solar energy for banana drying. Food Technology in Australia, 32 290-291. 
Carbonaro, M., Mattera, M. (2002) Polyphenoloxidase activity and polyphenol levels in original and conventionally grown peach (Prunus persica L., cv. Regina bianca) and pear (Pyrus communis L., cv. williams). Food Chemistry, 72419 424.

Dengate, H. N., Meredith, P. (1984) Inherent Variation in Wheat Starch Pasting Due Cultivar. Wiley online library, 36 (7) $238-240$.

Demirel, D., Turhan, M. (2003) Air Drying Behaviour of Dwarf Cavendish and Gros Michel Banana Slices. Journal of Food Engineering, 59 1-11.

Emperatriz, P. D., Ronald, M., Elvina, P., Mily, S. (2008) Production and Characterization of Unripe Plantain (Musa paradisiaca) flours. Interciencia, $33290-296$.

Fakayode, B. S., Rahji, M. A. Y., Ayinde, O., Nnom, G. O. (2011) An Economic Assessment of Plantain Production in Rivers State. Nigeria International Journal of Agricultural Economics an. Rural Development, 42.

Falade, K.O., Olugbuyi, A. O. (2010) Effects of Maturity and Drying Method on the Physico-chemical and Reconstitution Properties of Plantain Flour. International Journal of Food Science and Technology, 45 170-178.

FAO (2004) FAO. Available at: http://www.faostat.fao. org $(02 / 2008)$.

FAO (2009) Statistics Series No 95 FAO, Rome.

FAO (2011) Production, commodity by country; FAOSTAT Data. Food and Agriculture Organisation of the United Nations, Rome. Available at: http://faostat.fao.org/site/339/default.aspx. Accessed: 03.10.2001.

Ihekoronye, A.I., Ngoddy, P.O. (1985) Integrated Food Science and Technology for the Tropics. pp. 224-229. Macmillan Education Ltd, London.

IITA (2009) Yam Production in Africa. International Institute of Tropical Agriculture (IITA), Nigeria. Available at: http://www.iita.org.

Izonfuo, W.A., Omuaru, V.O. (1988) Effect of Ripening on the Chemical Composition of Plantain Peels and Pulps (Musa paradisiaca). Journal of Science Food Agriculture, 45 333-336

Kulkarni, D. N., Ingle U. M. (1991) Sorghum Malt Based Weaning Food Formulations: Preparation, Functional Properties and Nutritive Value. Food and Nutrition Bulletin, 13(4) 322-327.

Leach, H. W., McCoven, L. D., Scoch, T. J. (1959) Structure of the Starch Granule. Swelling and Solubility Patterns of Various Starches. Cereal Chemistry, 36 534-544.

Maziya-Dixon, B., Dixon, A. G. O., Adebowale A. A. (2004). Targeting Different End Uses of Cassava: Genotypic Variations for Cyanogenic Potentials and Pasting Properties. A Paper Presented at ISTRC-AB Symposium, 31 October - 5 November 2004, Whitesands Hotel, Mombassa, Kenya.

Mepba, H. D., Eboh, L., Nwaojigwa, S. U. (2007) Chemical Composition, Functional and Baking Properties of Wheatplantain Composite Flours. Africa Journal of Food Agriculture and Nutritional Development, 7(1) 1-22.

Moorthy, S. N. (2002) Physiochemical and Functional Properties of Tropical Tuber Starches; A Review, Starch and Starke, 54 559-592.
Mpotokwane, S. M., Gaditlhatlhelwe, E., Sebaka, A., Jideani, V. A. (2008) Physical properties of bambara groundnuts from Botswana. Journal of Food Engineering, 89 93-98.

Nelson, C., Scot, R. C., Ploetz, Angela, K. K. (2006) Musa Species (Banana and Plantain) Species Profiles for Pacific Island Agroforestry. Available at: www.traditionaltree.org.

Newport Scientific (1998). Applications Manual for the Rapid Visco TM Analyzer Using Thermocline for Windows. Newport Scientific Pty Ltd., 1/2 Apollo Street, Warriewood NSW 2102, Australia. pp. 2-26.

Nwosu, J. N., Onuegbu, N. C., Kabuo, N. O., Okeke, M. O. (2010) The Effect of Steeping with Chemicals (Alum and Trona) on the Proximate and Functional Properties of Pigeon pea (Cajanus cajan) Flour. Pakistan Journal of Nutrition, 9(8) 762-768.

Nyombi, K. (2010) Understanding Growth of Eat African Highland Banana. Experiment and Simulation. PhD thesis submitted at Wageningen University. ISBN. 978-90-8585-5507.

Olorunda, A. O., Adelusola, M. A. (1997) Screening of Plantain / Banana Cultivars for Import, Storage and Processing Characteristics. Paper Presented at the International Symposium on Genetic Improvement of Bananas for Resistance to Disease and Pests $7-9^{\text {th }}$ September, (IRAD, Montpellier, France).

Olumba, C. C. (2014) Productivity of Improved Plantain Technologies in Anambra State, Nigeria. African Journal of Agricultural Research, 9(29) 2196 - 2204.

Oluwalana, I. B. Oluwamukomi, M. O. Fagbemi, T. N., Oluwafemi, G. I. (2011) Effects of Temperature and Period of Blanching on the Pasting and Functional Properties of Plantain (Musa parasidiaca) flour. Journal of Stored Products and Postharvest Research, 2(8) 164 - 169.

Perez, E. (1997) Characterization of starch isolate from plantain (Musa paradisiacal normalis). Starch Starke, 4 45-49.

Sandhu, K. S. Singh, N., Malhi, N. S. (2007) Some Properties of Corn Grains and their Flours Physicochemical, Functional and Chapati-making Properties of Flours. Food Chemistry, 101 938-946.

Sathe, S.K., Salunkhe, D.E. (1981) Functional properties of lupid seed (Lupinus mutabilis) proteins and protein concentrates. Journal of Food Science, 46 149-197.

Shittu, T. A. Lasekan, O. O. Sanni, L.O., Oladosu, M. O. (2001) The Effect of Drying Methods on the Functional and Sensory Characteristics of Pukuru; a Fermented Cassava Product. ASSET-An International Journal of Agriculture, 1(2) 9-16.

Thomas, D. S., Atwell, W. A. (1999) Starch structure. In: Critical Guide for the Food Industry (Series Ed.), Starches. Eagan Press Handbook Series. St Paul, MN, USA: Eagan Press. pp. 1, 2, 25-30.

Zaidhul, I. S. M, Hiroaki, Y., Sun-Ju, K., Naoto, H., Takahiro, N. (2006) RVA Study of Mixtures of Wheat Flour and Potato Starches with Different Phosphorus Contents. Food Chemistry, doi:10.1016/j.foodchem.2006.06.056.

Zakpaa, H. D., Mak-Mensah, E. E., Adubofor, J. (2010) Production and characterization of flour produced from ripe 'apem' plantain (Musa sapientum L. var. parasidiacal; French horn) grown in Ghana. Journal of Agricultural Biotechnology and Sustainable Development, 2(6) 92-99. 